\title{
TYPICAL AND ATYPICAL NEUROLEPTICS: DIFFERENTIAL EFFECTS OF CHRONIC ADMINISTRATION ON THE ACTIVITY OF A9 AND A10 MIDBRAIN DOPAMINERGIC NEURONS ${ }^{1}$
}

\author{
LOUIS A. CHIODO ${ }^{2}$ AND BFN.JAMIN S. BUNNEY
}

Departments of Psychiatry and Pharmacology, Yale University School of Medicine, New Haven, Connecticut 06510

Received November 5, 1982; Revised March 7, 1983; Accepted March 7, 1983

\begin{abstract}
Extracellular single unit recording techniques were used to study the effects of both acute and repeated oral neuroleptic administration on the in vivo activity of rat A9 and A10 dopaminergic (DA) neurons. All antipsychotic drugs examined acutely (haloperidol, $l$-sulpiride, chlorpromazine, and clozapine) increased the number of spontaneously firing DA neurons in both A9 and A10 compared to controls. Repeated (21 day) treatment with haloperidol, $l$-sulpiride, and chlorpromazine (antipsychotic drugs which can cause extrapyramidal side effects) markedly reduced the number of active DA cells below control levels in both regions. The "silent" DA neurons were in an apparent state of tonic depolarization inactivation since they could be induced to discharge by the microiontophoretic application of the inhibitory neurotransmitter $\gamma$-aminobutyric acid, but not the excitatory amino acid glutamate. The depolarization inactivation observed may be specific for antipsychotic drugs since a non-neuroleptic phenothiazine (promethazine), the inactive isomer of sulpiride ( $d$ sulpiride), and a tricyclic antidepressant (desmethylimipramine) neither increased DA activity when given acutely nor induced depolarization inactivation when administered repeatedly. In contrast to the other drugs tested, repeated treatment with clozapine (an effective antipsychotic drug which does not producc extrapyramidal side effects) resulted in the depolarization inactivation of A10 neurons but not A9 cells. These data suggest that neuroleptics which can induce extrapyramidal side effects produce depolarization inactivation of both A9 and A10 neurons whereas antipsychotic drugs which lack this property inactivate only A10 neurons. It is suggested that the time-dependent development of A9 DA neuron inactivation induced by repeated neuroleptic treatment may provide a mechanism for understanding the delayed onset of extrapyramidal side effects often observed with these drugs.
\end{abstract}

Drugs which have as their primary action the blockade of central dopamine receptors (i.e., neuroleptics) are widely accepted as being the therapeutic agents of choice for the treatment of the major symptoms of psychosis (Klein et al., 1980). Unfortunately, neuroleptic treatment also can cause numerous side effects, including the often irreversible movement disorder tardive dyskinesia (Klawans, 1976; Klein et al., 1980; Jeste and Wyatt, 1982; Kane and Smith, 1982). In man, many of the therapeutic

\footnotetext{
${ }^{1}$ We thank McNeil Laboratories (haloperidol), Smith, Kline \& French Laboratories (chlorpromazine hydrochloride), Sandoz Pharmaceuticals (clozapine), Ravizza (sulpiride), and Wyeth Laboratories (promethazine) for generously supplying the drugs used in this study. We also thank Drs. M. J. Bannon and R. H. Roth for their helpful comments, Chen-Iun Pun for laboratory assistance, and Lynn Williams and Diane Bennett for manuscript preparation. This work was supported in part by United States Public Health Service Grants MH28849, MH-25642, and NS-07136 and by the State of Connecticut.

${ }^{2}$ To whom correspondence should be addressed.
}

actions and side effects of neuroleptics can take days to weeks, and in some cases months, to develop (Crane, 1973; Cotes et al., 1978; Beckman et al., 1979). For this reason, basic research has turned increasingly toward an investigation of the effects of chronic neuroleptic treatment on neuronal systems. Such studies have often demonstrated marked differences between the effects of acute administration of a drug and the effects produced by repeated administration. For example, although it is well established that the biochemical consequence of acute dopamine (DA) receptor blockade is a compensatory increase in DA turnover (Carlsson and Linqvist, 1963; Nyback et al., 1967; Nyback and Sedvall, 1970; Anden and Stock, 1973; Hyttel, 1974; Roth et al., 1975; Wilk et al., 1975; Zivkovic et al., 1975; Wilk and Stanley, 1978; Meller et al., 1980; Bannon et al., 1983), these effects are greatly diminished (i.e., tolerance develops) during repeated treatment with these compounds (Bowers and Rozitis, 1974; Scatton et al., 1975; Laduron et al., 1977; 
Lerner et al., 1977; Scatton, 1977, 1980; Meller et al., 1980; Wheeler and Roth, 1980; Bacopoulos et al., 1982; Bannon et al., 1982a). A second example is provided by electrophysiological studies. Thus, acute neuroleptic administration increases (Bunney et al., 1973; Bunney and Grace, 1978; Bunney, 1979), whereas repeated administration (21 days) decreases, the number of spontaneously active DA neurons located within the zona compacta region of the substantia nigra (Bunney and Grace, 1978). In the latter case, the inactive DA cells could be induced to fire by the microiontophoretic application of the inhibitory neurotransmitter $\gamma$-aminobutyric acid but not by the excitatory amino acid glutamate, suggesting that they were in a state of tonic depolarization inactivation.

In these early electrophysiological experiments, only DA neurons in the substantia nigra zone compacta (A9 area; Dahlstrom and Fuxe, 1964) were studied. However, when considering the actions of chronic neuroleptic administration on central DA neurons, it has become increasingly apparent that one needs to examine their effects upon several anatomically and/or functionally distinct DA systems. For example, it is generally accepted that the extrapyramidal side effects which accompany neuroleptic treatment are due primarily to their actions on the nigrostriatal DA system (Barbeau, 1969; Klawans and McKendall, 1971; Baldessarini and Tarsy, 1976, 1980; Sovner and DiMascio, 1978). The cells of origin for this DA system are located within the A9 areas and terminate mainly within the caudate nucleus (Hokfelt et al., 1974; Bunney and Aghajanian, 1976; Lindvall and Bjorklund, 1978; Lindvall, 1979). On the other hand, the antipsychotic properties of these compounds have been suggested to be mediated via their effects on mesolimbic and mesocortical DA systems (Snyder, 1972; Matthysse, 1973; Stevens, 1973; Hokfelt et al., 1974; Snyder et al., 1974; Glowinski, 1975; Meltzer and Stahl, 1976). The cell bodies of these DA neurons are located predominantly within the ventral tegmental area (region A10 of Dahlstrom and Fuxe, 1964) and project mainly to the limbic and cortical regions (Berger et al., 1974, 1976; Berger, 1977; Lindvall et al., 1977; Lindvall and Bjorkland, 1978; Lindvall, 1979; Swanson, 1982). In the present study we examined the effects of both acute and repeated (21 day) oral administration of a variety of neuroleptics on the spontaneous activity of DA neurons located in both the $\mathrm{A} 9$ and $\mathrm{A} 10$ regions. Haloperidol, chlorpromazine, and $l$ sulpiride were studied because they represent three dif- ferent chemical classes of neuroleptics which are both clinically effective and associated with the development of extrapyramidal side effects. Clozapine was tested because, although therapeutically active (Gerlach et al., 1974; Chouinard and Annable, 1976; Shopsin et al., 1979), it has not been associated with the induction of these side effects (Gerlach et al., 1975). For purposes of comparison, we also examined the effects, on DA cell activity, of acute and chronic treatment with the inactive isomer of sulpiride ( $d$-sulpiride), the non-neuroleptic phenothiazine promethazine, and the antidepressant desmethylimipramine.

\section{Materials and Methods}

Animals and drug treatment. Male Sprague-Dawley albino rats (Charles-River), weighing 200 to $225 \mathrm{gm}$ at the start of the experiment, were used throughout the study. They were housed two per cage and maintained on a controlled 12-hr light: 12 -hr dark cycle, with free access to food and water. In the acute studies, animals were given one of the following drugs via intragastric intubation: haloperidol (HAL; $0.5 \mathrm{mg} / \mathrm{kg}$ ), $l$-sulpiride $(l$ SLP; $20 \mathrm{mg} / \mathrm{kg}$ ), $d$-sulpiride ( $d$-SLP; $20 \mathrm{mg} / \mathrm{kg}$ ), chlorpromazine (CPZ; $5 \mathrm{mg} / \mathrm{kg}$ ), clozapine (CLZ; $20 \mathrm{mg} / \mathrm{kg}$ ), promethazine (PRO; $19 \mathrm{mg} / \mathrm{kg}$ ), or desmethylimipramine (DMI; $10 \mathrm{mg} / \mathrm{kg}$ ). In the chronic studies another group of animals was given these drugs in their drinking water for 21 consecutive days. When averaged over 21 days of treatment, the mean daily dose for each drug was: HAL: $0.56 \pm 0.08 \mathrm{mg} / \mathrm{kg} ; l-\mathrm{SLP}: 21.15 \pm 0.42 \mathrm{mg} / \mathrm{kg} ; d$-SLP: $19.99 \pm 0.40 \mathrm{mg} / \mathrm{kg}$; CPZ: $5.56 \pm 0.08 \mathrm{mg} / \mathrm{kg}$; CLZ: 24.45 $\pm 0.74 \mathrm{mg} / \mathrm{kg}$; PRO: $19.25 \pm 0.62 \mathrm{mg} / \mathrm{kg}$; and DMI: 11.40 $\pm 0.23 \mathrm{mg} / \mathrm{kg}$ (Table I). Untreated control animals were also sampled for the purpose of comparison. All chronically treated animals were weighed twice a week and the drugs placed in light-proof drinking bottles. No significant difference in weight gain was scen in any of the treatment groups. Daily water intakes were measured for each cage and the actual dose of drug the animals received was calculated from these values (see "Results"). All drug doses are expressed as the weight of their salt.

Electrophysiological methods. One hour after acute treatment, or on day 21 of repeated administration, a given animal was anesthetized with chloral hydrate ( 400 $\mathrm{mg} / \mathrm{kg}$, i.p.) and placed in a stereotaxic apparatus. In all cases the experimenter was blind with respect to the

'I'ABLE' I

Mean daily oral drug intake for the 3 consecutive weeks of repeated drug treatment ${ }^{a}$

\begin{tabular}{|c|c|c|c|c|c|}
\hline Treatments & $\begin{array}{l}\text { No. of } \\
\text { Animals }\end{array}$ & Week 1 & Week 2 & Week 3 & $\begin{array}{c}\text { Overall } \\
\text { Average } \\
\text { Daily } \\
\text { Intake }\end{array}$ \\
\hline HAL & 12 & $0.53 \pm 0.01$ & $0.57 \pm 0.01$ & $0.55 \pm 0.01$ & $0.56 \pm 0.02$ \\
\hline CPZ & 10 & $5.71 \pm 0.15$ & $5.44 \pm 0.09$ & $5.52 \pm 0.15$ & $5.56 \pm 0.08$ \\
\hline $\mathrm{CLZ}$ & 8 & $25.50 \pm 1.72$ & $24.65 \pm 1.10$ & $23.00 \pm 0.64$ & $24.45 \pm 0.74$ \\
\hline$l$-SLP & 8 & $21.67 \pm 0.56$ & $21.93 \pm 0.47$ & $19.58 \pm 0.89$ & $21.15 \pm 0.42$ \\
\hline$d$-SLP & 8 & $19.56 \pm 0.54$ & $19.22 \pm 0.97$ & $20.58 \pm 0.47$ & $19.99 \pm 0.40$ \\
\hline PRO & 8 & $17.50 \pm 1.03$ & $21.13 \pm 1.03$ & $19.04 \pm 0.59$ & $19.25 \pm 0.62$ \\
\hline DMI & 9 & $10.69 \pm 0.46$ & $12.11 \pm 0.20$ & $11.39 \pm 0.26$ & $11.40 \pm 0.23$ \\
\hline
\end{tabular}

${ }^{a}$ Data represented as mean $\pm \mathrm{SEM}, \mathrm{mg} / \mathrm{kg}$. 
treatment condition of the animal. Body temperature was monitored and maintained between 36 and $37^{\circ} \mathrm{C}$. After reflecting the scalp, the skull overlying both the substantia nigra (A9; anterior 1,750 to $2,580 \mu \mathrm{m}$, lateral 2,100 to $1,700 \mu \mathrm{m}$, Konig and Klippel, 1974) and the ventral tegmental area (A10; anterior 1,610 to $2,420 \mu \mathrm{m}$, lateral 100 to $500 \mu \mathrm{m}$ ) was removed. Extracellular neuronal signals were sampled using a single barrel micropipette (overall tip diameter less than $1 \mu \mathrm{m}$ ) filled with $2 \mathrm{M} \mathrm{NaCl}$ containing $2 \%$ pontamine sky blue dye (in vitro impedance measured at $135 \mathrm{~Hz}, 4$ to 8 megohms). These signals were passed to a high input impedance amplifier (bandpass settings: $120 \mathrm{~Hz}$ to $3 \mathrm{kHz}$ ) whose output was led to an oscilloscope and audio monitor. Firing rates were calculated on-line by a rate-averaging computer. Spontaneously firing DA cells within both the $\mathrm{A} 9$ and $\mathrm{A} 10$ regions were counted by lowering the electrode through a block of tissue $\left(120,000 \mu \mathrm{m}^{2}\right.$, Fig. 1) which could be reproducibly located from animal to animal. Twelve electrode tracks (separated from each other by $200 \mu \mathrm{m}$ ), whose sequence was kept constant from animal to animal, were made in each region. Only cells whose electrophysiological characteristics matched those previously established for midbrain DA-containing neurons (Bunney et al., 1973; Grace and Bunney, 1980, $1983 \mathrm{a}, \mathrm{b}$ ) were sampled.

In the microiontrophoretic experiments five-barrel micropipettes (overall tip diameter 4 to $7 \mu \mathrm{m}$ ) were employed as previously described (Aghajanian and Bunney, 1977). The center barrel was filled with $2 \mathrm{M} \mathrm{NaCl}$ containing $2 \%$ pontamine sky blue dye (in vitro impedance at $135 \mathrm{~Hz}, 4$ to 8 megohms). One of the side barrels was filled with $3 \mathrm{M} \mathrm{NaCl}$ and was used for the automatic neutralization of tip currents (Salmoraghi and Weight, 1967). The other three outer barrels were filled with either $\gamma$-aminobutyric acid (GABA; $0.05 \mathrm{M}, \mathrm{pH} 4.0$, Sigma) or glutamic acid (GLU; $0.01 \mathrm{M}$ in $0.01 \mathrm{M} \mathrm{NaCl}$, $\mathrm{pH}$ 8.0, Sigma). A retaining current of $10 \mathrm{nA}$ was used to eliminate the passive diffusion of drug.

In some studies cells were identified according to their area of projection by antidromic activation from the region they innervated. In these experiments concentric bipolar electrodes (SNE-100, David Kopf Instruments) were stereotaxically placed in the region of the prefrontal cortex (anterior 9,650 to 11,050, lateral 200 to 1,000 ; Konig and Klippel, 1974). Constant current (0.3 to 3.0 $\mathrm{mA}$ ) square wave pulses of $500-\mu \mathrm{sec}$ duration were employed. Neurons were considered antidromically activated when the following criteria were met: (1) one antidromic spike per stimulation, (2) a fixed latency for the stimulus-induced action potential, (3) stimulation rates of $100 \mathrm{~Hz}$ could be followed by the antidromically driven cell, and (4) collision was observed between spontaneously occurring action potentials and the antidromic spike.

Recording sites were marked by passing a $-30 \mu \mathrm{A}$ current through the recording barrel for $10 \mathrm{~min}$ which resulted in the ejection of a $50-\mu \mathrm{m}$ diameter spot of blue dye. The rats were perfused with a phosphate-buffered $10 \%$ formalin solution, and the brain was removed. Serial frozen sections were cut at $50-\mu \mathrm{m}$ intervals and stained with a formal-thionin solution (Donovick, 1974). A light
AlO

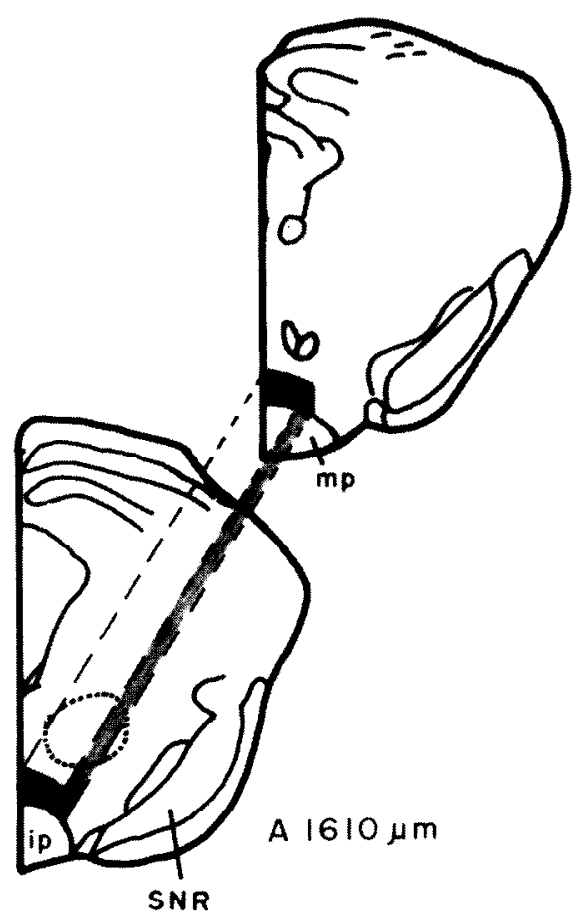

A9

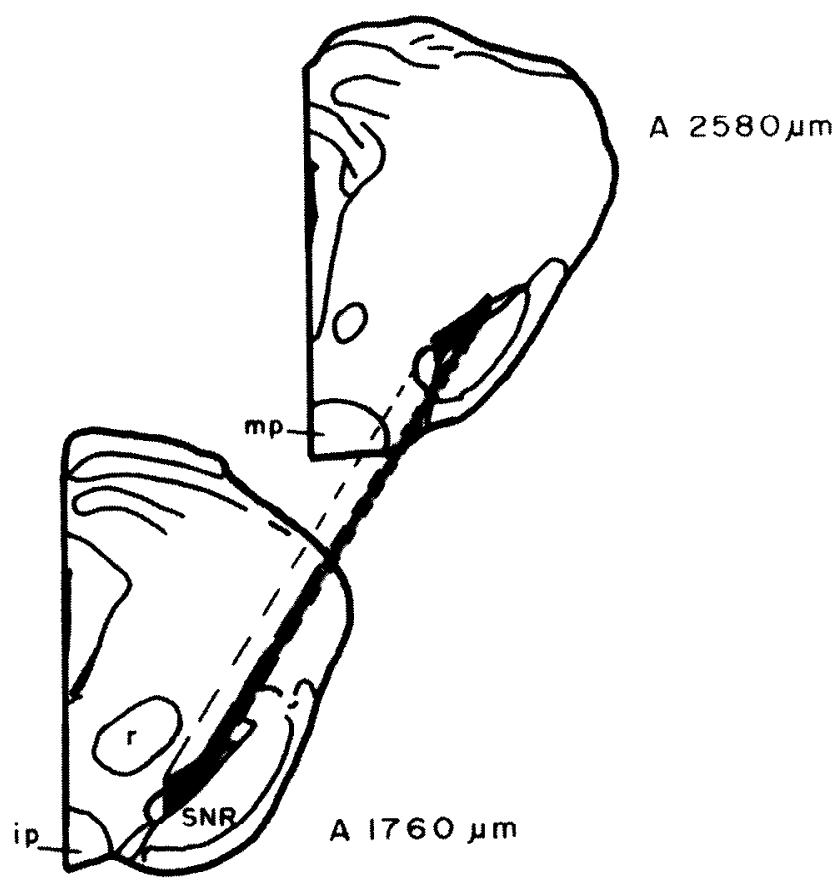

Figure 1. Schematic drawing (modified from Konig and Klippel, 1974) showing the location of the stereotaxically defined blocks of tissue within A9 and A10 in which all electrode tracks were made. SNR, substantia nigra, zona reticulata; mp, nucleus mammilaris posterior; ip, nucleus interpeduncularis. 
microscope was then used to locate each spot of ejected dye. Histological examination verified that all of the electrode tracks placed in the present series of experiments were located within the blocks of tissue defined as $\mathrm{A} 9$ and $\mathrm{A} 10$ in Figure 1.

Overall statistical significance between groups was determined by an analysis of variance. Post-hoc paired comparisons of individual group differences were conducted using the Dunnett test (two-tailed $t$ statistic).

\section{Results}

In the untreated control animals the mean number of DA neurons encountered in the A9 and A10 regions was 0.81 and 0.86 cells/track, respectively (Fig. 2). The average spontaneous firing rate of the cells sampled was 4.1 and 4.6 spikes/sec, respectively. In contrast, the acute administration of each of the antipsychotic drugs tested ( $l$-SLP, HAL, CPZ, and CLZ) produced a 2- to 3 -fold increase in the number of cells per track in both A9 and A10. However, acute treatment with the non-neuroleptic phenothiazine, $\mathrm{PRO}$, the inactive isomer of sulpiride, $d$ SLP, or the tricyclic antidepressant, DMI, had no effect on the number of DA neurons observed in A9 or A10.

In contrast to these acute effects, animals repeatedly treated for 21 days with HAL, CPZ, or $l$-SLP had markedly fewer active DA neurons in A9 and A10 when compared to untreated controls (Fig. 2). For example, in the HAL-treated animals we observed only 0.19 and 0.16 cells/track in A9 and A10, respectively. Repeated CLZ treatment, on the other hand, had a strikingly different effect upon A9 and A10 DA neurons (Fig. 2). Whereas a marked reduction in the number of cells in A10 was observed $(0.25$ compared to 0.86 cells/track in control animals), there was an increased number of spontaneously firing DA neurons in A9 (1.59 compared to 0.81 cells/track in controls).

The repeated administration of the non-neuroleptic phenothiazine, $\mathrm{PRO}$, and the inactive isomer of sulpiride, $d$-SLP, had no effect on either the number of A9 or A10 cells encountered or their spontaneous activity (Fig. 2).

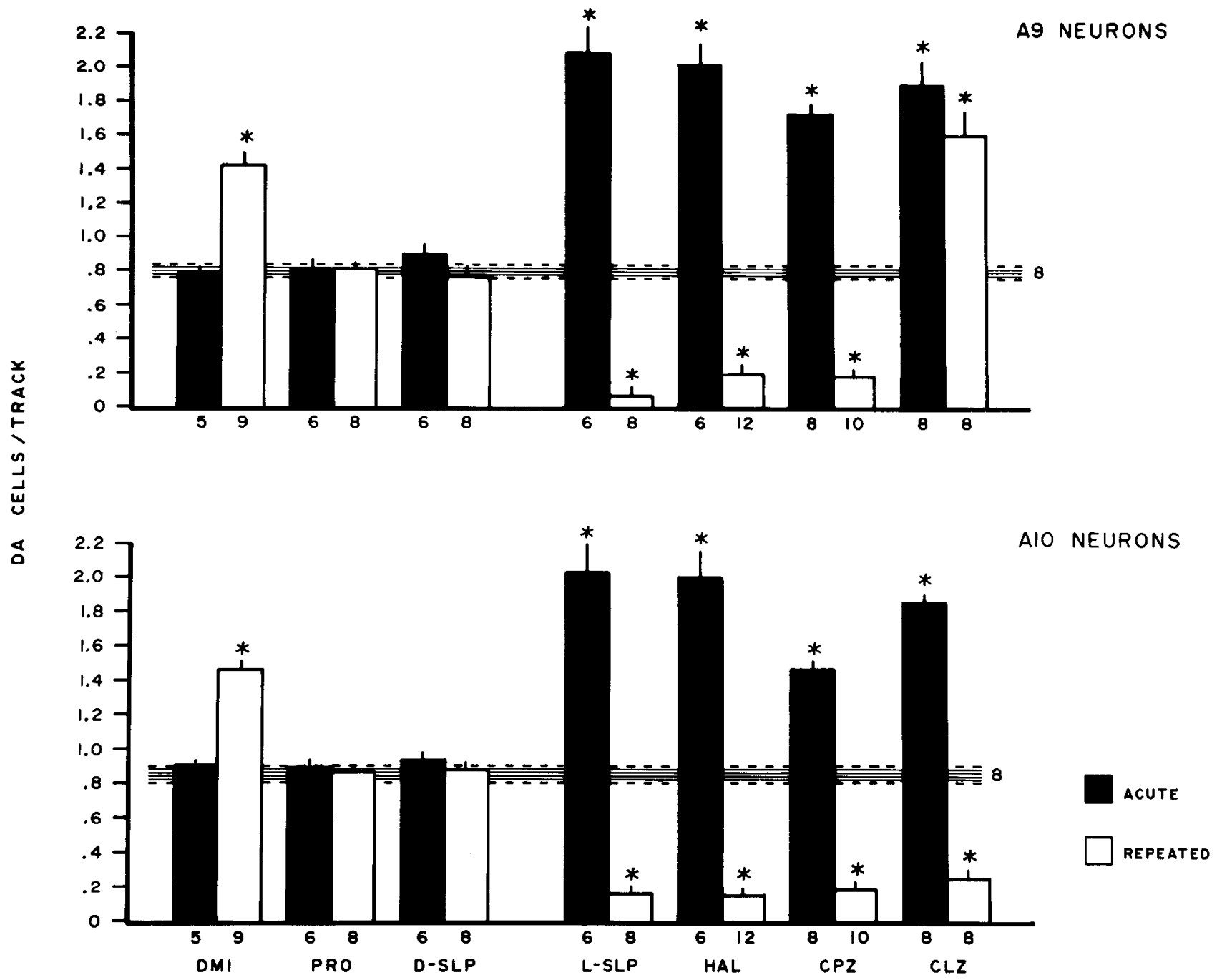

Figure 2. The effects of both acute and repeated (21 day) oral neuroleptic administration on the mean ( \pm SEM) number of spontaneously firing DA cells per track encountered in both A9 and A10. The shaded areas represent the control means $( \pm$ SEM) obtained for untreated animals. $D M I$, desmethylimipramine; $P R O$, promethazine; $D$ - $S L P, d$-sulpiride; $L$-SLP, $l$-sulpiride; $H A L$, haloperidol; $C P Z$, chlorpromazine; $C L Z$, clozapine. $*, p<0.01$ relative to untreated controls, two-tailed Dunnett test. Number below each bar indicates the number of animals studied. 
Chronic treatment with the antidepressant DMI, which is not a DA receptor antagonist and does not produce extrapyramidal side effects when given chronically, significantly increased the number of neurons seen in both A9 and A10 (1.42 and 1.66 cells/track, respectively; Fig. 2).

Previous work has demonstrated that the neurochemical (kainic acid) destruction of striatonigral and pallidonigral feedback pathways prior to repeated HAL administration prevents the induction of depolarization block (Bunney and Grace, 1978). Given this observation,

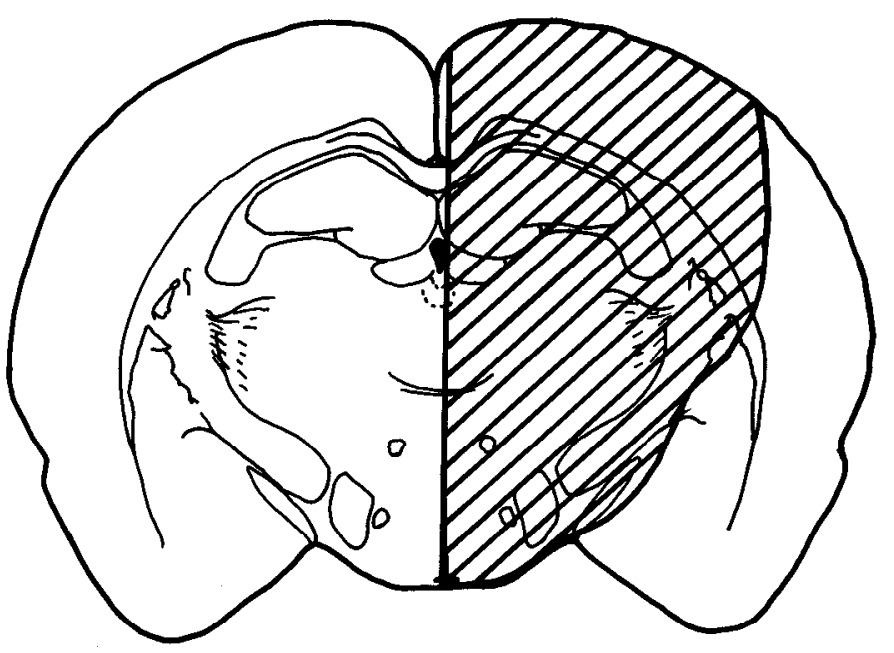

A 4380

Figure 3. Schematic drawing (modified from Konig and Klippel, 1974) showing the region of transection (shaded area) for the animals represented in Figure 4. we examined the effects of acute hemitransection of the forebrain (immediately prior to recording) on the number of active DA neurons present in chronically CPZ-treated animals (6 of the 10 animals represented in Fig. 2). In half the animals, active DA cells were counted on one side of the brain and immediately thereafter a glass microknife was stereotaxically lowered into the opposite hemisphere (at the level of the tail of the caudateputamen (anterior 4230 to $4620 \mu \mathrm{m}$; Konig and Klippel, 1974), and the diencephalon was totally transected (Fig. 3 ). Recordings were immediately made from the A9 and A10 regions of the transected side. In the other three animals the knife cut was made first and the lesioned side was sampled before the intact side. As shown in Figure 4, the transection reversed the depolarization inactivation normally produced by $\mathrm{CPZ}$ in A9 neurons while not changing the chronic effects of this drug in A10 neurons. In fact, knife cuts significantly elevated the number of A9 DA cells/track compared to unlesioned untreated animals (post-transection: 1.72 cells/track compared to 0.81 cells/track in control animals). In untreated animals, knife cuts did not alter the cells/tract in either $\mathrm{A} 9$ or $\mathrm{A} 10(N=4)$. Average firing rates were not different in these two conditions and were similar to control values.

Part of the initial evidence indicating that the inactive A9 DA neurons were in fact in a state of depolarization block arose from the observation that these cells could be induced to fire by the microiontophoretic application of the inhibitory neurotransmitters GABA and DA, but not the excitatory amino acid GLU (Bunney and Grace, 1978). We used the same experimental approach to determine if A10 DA neurons were also not firing due to an apparent depolarization inactivation. In chronically

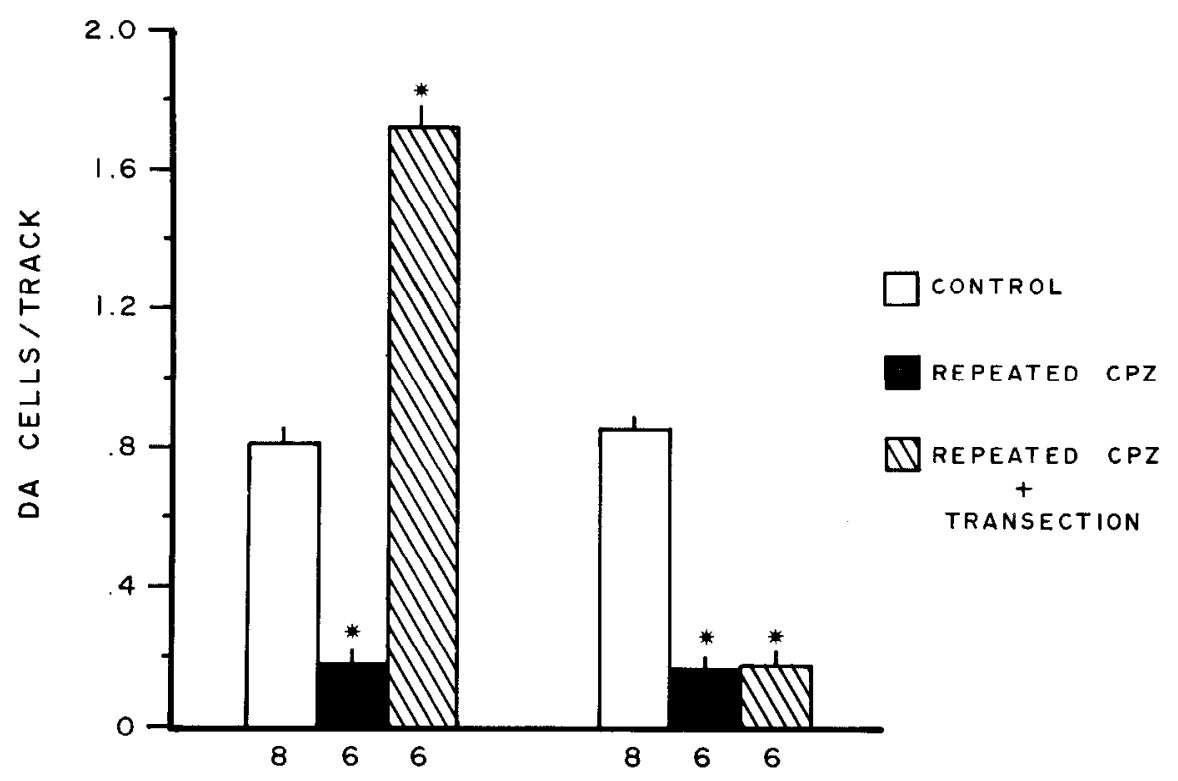

Figure 4. The effects of acute unilateral hemitransection of the forebrain on the mean ( \pm SEM) number of A9 and A10 spontaneously firing DA cells per track observed in animals treated for 21 days with chlorpromazine $(C P Z) . *, p<0.01$ relative to control, two-tailed Dunnett test. Number below each bar indicates the number of animals studied. 
CPZ-treated animals multiple electrode passes were made through the zona compacta (number of animals, $N$ $=10$ ) while GABA was being pulsed from the pipette. Low ejection currents ( 1 to $5 \mathrm{nA}$ ) caused the onset and subsequent emergence of DA neuronal activity (identified by their electrophysiological characteristics) from the background noise (Fig. 5). At first these GABAactivated neurons were firing rapidly and displayed relatively small amplitude action potentials. As the GABA application continued, the discharge rate slowed (i.e., interspike interval increased) and the action potential amplitude increased. If GABA iontophoresis was immediately discontinued these cells would then increase in rate while decreasing in amplitude until no longer discernible above the noise. When GABA iontophoresis was continued for approximately 30 to $60 \mathrm{sec}$, these activated DA neurons would continue to discharge spontaneously in a normal manner (e.g., display normal bursting patterns). Further application of GABA at higher ejection currents totally inhibited DA activity. The extracellular

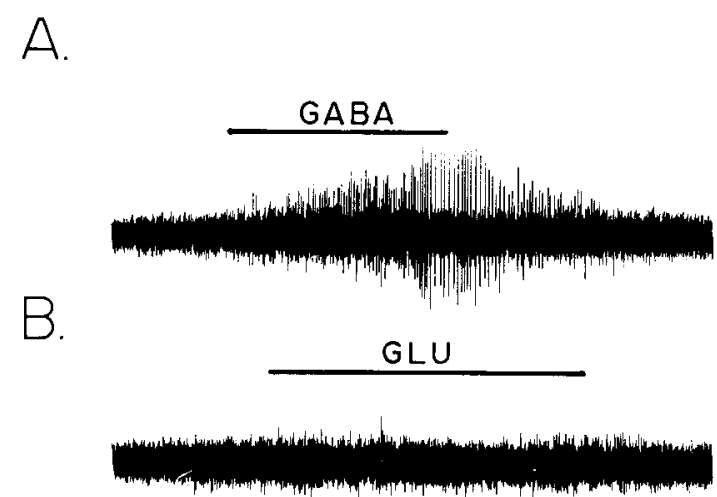

Figure 5. $A$ and $B$, Oscillograph tracings showing typical responses of a "silent" A10 DA neuron to glutamic acid ( $G L U$ ) and $\gamma$-aminobutyric acid $(G \Lambda B \Lambda)$ in an animal chronically treated with chlorpromazine. $A$, This cell was activated by the microiontophoretic application of GABA (ejection current equals $3 \mathrm{nA}$ ). Note that after a short delay GABA causes the cell to appear out of the background noise. Continued application of GABA results in a decrease in activity (action potential amplitude increases and duration decreases). When the GABA is turned off, the rate of the cell markedly increases (action potential amplitude decreases and duration markedly increases) and the spikes disappear back into the noise. (The changes in spike duration are not visible due to the paper speed employed. These changes in action potential amplitude and duration are identical to those observed in untreated animals when the spontaneous activity of a DA cell increases or decreases (Bunney et al., 1973; Aghajanian and Bunney, 1977; Grace and Bunney, 1983a, b). Under both conditions, due to the fact that dopamine cells can change from a slow irregular firing mode to a fast bursting mode with decreasing spike amplitudes within each burst, the spike height can vary enormously within a very short period of time (less than $100 \mathrm{msec}$ ). $B$, The lower trace shows that the excitatory amino acid GLU (ejected at $12 \mathrm{nA} 1$ min after the GABA ejection shown in the upper trace) was unable to activate the "silent" DA neuron. Horizontal bars represent the onset and duration of the iontophoretic drug application. Calibration equals $400 \mu \mathrm{V}$ and $2 \mathrm{sec}$. action potentials observed for these GABA-activated silent DA neurons were identical to those previously reported for midbrain DA neurons (Bunney et al., 1973; Guyenet and Aghajanian, 1978; Bunney, 1979; Grace and Bunney, 1980; see Fig. 6C). The subsequent local application of GLU (10 to $20 \mathrm{nA}$ ) onto "silent" DA neurons, which had been previously identified by transient GABA activation, did not induce ccll firing in any of the cells tested (Fig. $5 ; N=12$ ). This ability of locally applied GABA to induce activity in nonfiring DA cells was observed for both $\mathrm{A} 9(N=12)$ and $\mathrm{A} 10(N=24)$ neurons. In a similar fashion we were able to induce inactive A10 DA cells to fire with GABA, but not GLU, in animals repeatedly treated with $\mathrm{HAL}(N=10$; Fig. 5). In control animals, the microiontophoretic application of GABA and GLU at the concentrations and currents used in the present study exerted their normal respective inhibitory and excititory effects on DA neuron activity.

In the animals chronically treated with neuroleptics, we consistently observed a small group of spontaneously active A10 DA neurons which apparently did not develop depolarization block. These neurons had firing charac-

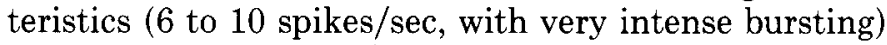
similar to previously identified A10 DA neurons which project to the prefrontal cortex and which have been shown to be devoid of both nerve terminal and somatic/ dendritic autoreceptors (Bannon et al., 1981, 1982b). To determine if the spontaneously firing A10 DA neurons observed in our chronically treated animals were in fact the same subpopulation of DA cells, attempts were made to antidromically activate them by means of prefrontal cortex stimulation. Of 10 neurons tested in HAL-treated animals, 8 met criteria for antidromic activation from the prefrontal cortex (Fig. 6). These antidromically activated neurons had fixed conduction latencies of 18.9 to $22.8 \mathrm{msec}$ (mean $\pm \mathrm{SEM}, 20.5 \pm 0.7$ ). For straight-line distances between the stimulating and recording electrode of 8.9 to $11.0 \mathrm{~mm}$, these values correspond to an estimated conduction velocity of 0.47 to $0.58 \mathrm{~m} / \mathrm{sec}$. This is similar to values previously reported for DA neurons (Deniau et al., 1978; Guyenet and Aghjanian, 1978; Grace and Bunney, 1980; Chiodo, 1981; Wang, 1981).

\section{Discussion}

Methodological considerations. Several difficulties are associated with the use of single unit extracellular electrophysiological techniques in studying the cffects of repeated drug administration on brain neuronal activity. Presently available techniques do not allow us to record from the same individual cell for the entire 21 days of drug administration. Therefore, we must make comparisons between populations of DA neurons sampled in both control and drug-treated (acute or chronic) animals. As we have previously reported for A9 DA neurons (Bunney and Grace, 1978), the probability of recording from the same population of DA cells in different animals is greatly increased by stereotaxically defining blocks of tissue within the zona compacta region and ventral tegmental area which can be reproducibly located in each animal. Since subsequent histology was conducted to ensure that all the electrode tracks made in our study were inside the confines of the stereotaxically defined 


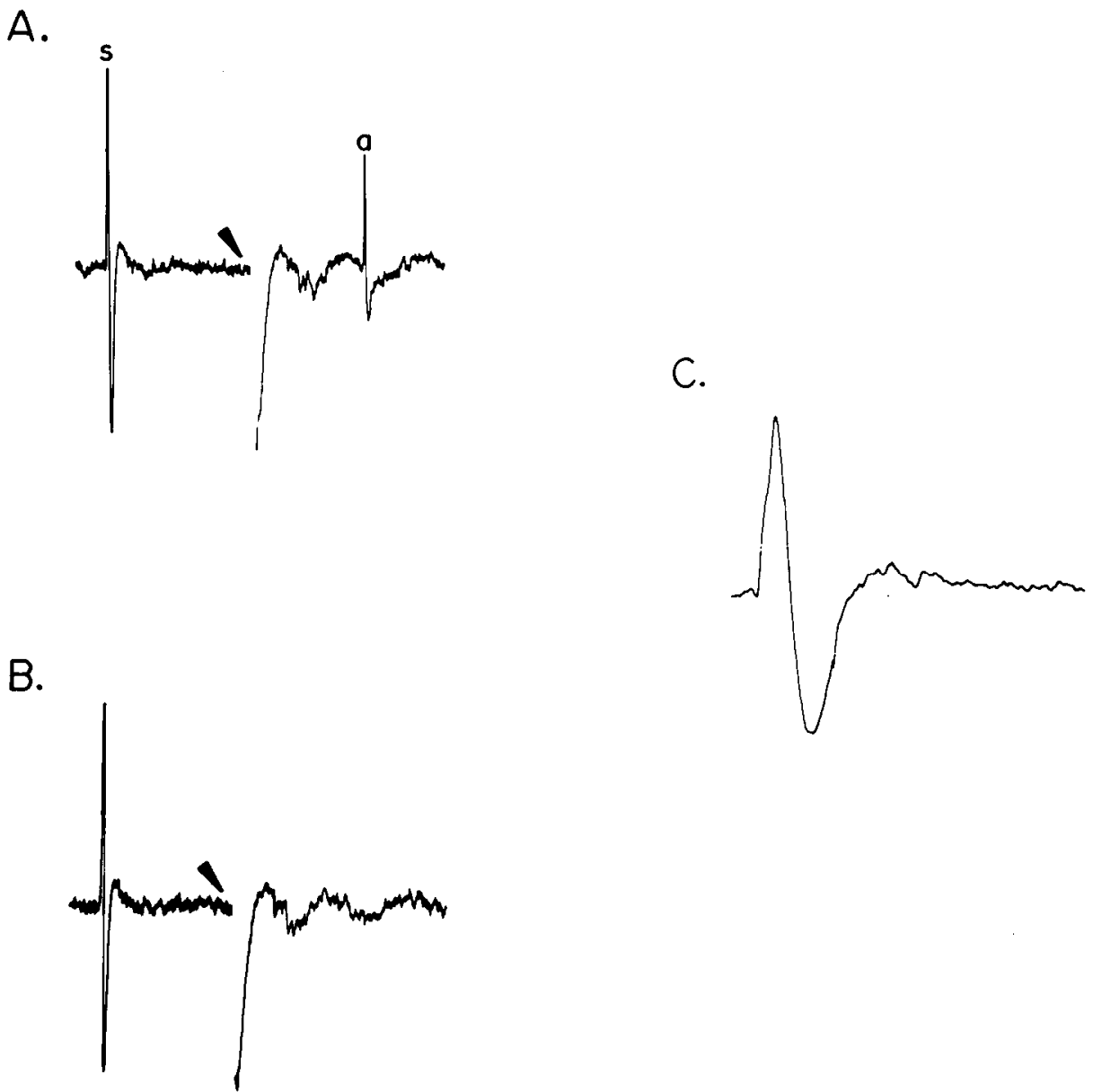

Figure 6. $A$ and $B$, Digital oscilloscope tracing showing the antidromic activation from the prefrontal cortex of a spontaneously active A10 DA neuron in an animal treated with HAL for 21 days. $A$, The spontaneously occurring action potential $(s)$ triggers the electrical stimulation (arrows; $1.9 \mathrm{~mA}, 500-\mu$ sec duration) after a delay of 24.0 msec. This produces an antidromic spike ( $a$, latency, $18.5 \mathrm{msec}$ ). The reduced amplitude of the antidromic spike compared to the spontaneous action potential is due to activation of only the initial segment component. $B$, Stimulation $21.5 \mathrm{msec}$ after the spontaneous spike occurs fails to antidromically activate this cell, demonstrating that collision has occurred. Calibration $=$ $200 \mu \mathrm{V}, 10 \mathrm{msec}$. C, An individual action potential of a "silent" A10 DA neuron which has been activated by the microiontophoretic application of GABA ( $4 \mathrm{nA})$. Calibration $=100$ $\mu \mathrm{V}, 2$ msec.

areas of A9 and A10 shown in Figure 1, it would seem likely that comparisons were made between the same populations of cells in the different treatment groups.

Experimental findings. In our previous work we demonstrated that daily subcutaneous injections (21 days) of the butyrophenone neuroleptic HAL $(0.5 \mathrm{mg} / \mathrm{kg})$ resulted in a marked decrease in the number of spontaneously firing A9 DA neurons. More recently, a report by White and Wang (1983) has demonstrated that chronic HAL progressively reduces the number of active DA neurons in both $\mathrm{A} 9$ and $\mathrm{A} 10$. The present study extends these earlier observations in several ways. First, we have shown that, regardless of structure (e.g., the butyrophenone HAL, the phenothiazine CPZ, the benzamide $l$-SLP, and the dibenzodiazepine CLZ), the acute administration of a neuroleptic will increase the number of active DA neurons in both A9 and A10. Second, the daily oral administration of a variety of antipsychotic drugs, all of which produce neurological effects (i.e., HAL, CPZ, and $l$-SLP), decreases the number of spontaneously active DA neurons in both these regions. In agreement with earlier reports (Bunney and Grace, 1978; White and Wang, 1983), the "silent" DA neurons observed in animals receiving neuroleptics chronically appear inactive due to excessive depolarization. This notion is supported by the fact that treatments which normally inhibit DA cell activity (systemic APO, iontophoretically applied DA or GABA) can induce silent cells to discharge in a normal fashion whereas excitatory agents (iontophoretically applied GLU) cannot induce activity (see Bunney and Grace, 1978; White and Wang, 1983). However, since only extracellular recording data (which do not allow for the determination of the resting membrane potential) have been reported to date, the possibility that silent DA neurons are in a state of depolarization inactivation must still be considered tentative. Intracellular electrophysio- 
logical studies are currently under way to examine DA neurons in animals treated chronically with neuroleptics.

The above effects appear specific for neuroleptics since control compounds such as the non-neuroleptic phenothiazine, PRO, the inactive isomer of sulpiride, $d$-SLP, and the antidepressant, DMI, did not increase the number of DA neurons observed when administered acutely nor decrease the number of active DA cells in either brain region when given chronically (even at the relatively high doses we employed). Although DMI had no effect when given acutely, repeated administration did increase the number of active DA neurons in both A9 and A10. This is in agreement with previous electrophysiological and biochemical findings demonstrating that repeated, but not acute, antidepressant administration alters the functioning of midbrain DA systems (Chiodo and Antelman, 1980; Serra et al., 1979, 1981; Holcomb et al., 1982).

A third extension of our earlier findings is the discovery that an ipsilateral hemisection between the striatum and substantia nigra, immediately prior to recording from chronically CPZ-treated animals, selectively reverses the observed inactivation of A9 neurons. This observation supports our previous finding (Bunney and Grace, 1978) that the feedback regulation normally provided by the striatonigral and pallidonigral pathways is critical for the expression of depolarization inactivation in A9. Together, these observations also suggest that the A9 neuron autoreceptor supersensitivity produced by chronic neuroleptics (Gallager et al., 1978; Bannon et al., 1980; Wheeler and Roth, 1980; Serra et al., 1981) is not a significant factor in the control of the firing rate of DA cells under these conditions. Theoretically, the development of supersensitive autoreceptors on DA cell bodies and dendrites would be expected to result in increased self-inhibition of DA neurons (Groves et al., 1975; Aghajanian and Bunney, 1977) and not depolarization.

When combined with our lesioning data, the fact that $l$-SLP, a putative selective $\mathrm{D}_{2}$-receptor antagonist (Kebabian and Calne, 1979; O'Conner and Brown, 1982), was able to decrease the number of active DA neurons to the same extent as theother neuroleptics studied suggests that $D_{2}$ receptors on the long-loop striatonigral feedback pathways may be important for the induction and maintenance of depolarization inactivation. It is not known why acute hemitransections were unable to reverse the chronic CPZ-induced inactivation of $A 10$ neurons. Since, as seen in Figure 3, the knife cuts totally transected the midbrain from forebrain structures, this finding may suggest that mechanisms other than longloop feedback regulation from forebrain regions are involved in the depolarization inactivation of these DA neurons.

A fourth extension of our earlier work is the finding that the clinically effective antipsychotic drug CLZ, which does not produce extrapyramidal side effects, has an effect very different from that observed with the other antipsychotic drugs. Thus, although repeated treatment with CLZ reduced the number of spontaneously active DA neurons encountered in A10, it increased the number of DA cells spontaneously firing in A9. Moreover, this increase in the number of active DA neurons in A9 was no different from the effects observed $1 \mathrm{hr}$ after acute CLZ treatment. Although the dose of CLZ employed in this study was high $(25 \mathrm{mg} / \mathrm{kg})$, the differential effect of chronic treatment with this drug on A9 and A10 DA cells cannot be attributed to the use of a relatively high dose because identical results were obtained with the repeated administration of $10 \mathrm{mg} / \mathrm{kg} /$ day for 21 days $(N=12)$ (L. A. Chiodo and B. S. Bunney, unpublished data).

At the present time, it is not clear why repeated CLZ treatment is unable to induce depolarization inactivation in A9 neurons while all other neuroleptics tested did. There are several possible explanations. First, it has been suggested on the basis of both receptor binding (Snyder et al., 1974; Miller and Hiley, 1974; Pelham and Munsat, 1979; Racagni et al., 1980) and DA turnover studies (Anden and Stock, 1973; Marco et al., 1976) that CLZ does not cause extrapyramidal side effects because it also exerts an anticholinergic action within the brain. However, in vivo physiological studies have shown that CLZ, even at relatively high doses, is a weak antagonist of the acetylcholine-induced excitation of neurons located in the zona reticulata of the substantia nigra (Aghajanian and Bunney, 1974). It is not known at present whether CLZ is also a weak antagonist of the physiological effects of acetylcholine in other relevant aminergic regions (e.g., striatum). Second, it has been shown that CLZ is also an $\alpha$-noradrenergic (NE) receptor antagonist (Bartholini et al., 1972; Burki et al., 1974; McMillen and Shore, 1978; Souto et al., 1979) which might, in part, account for its differential effect on A9 neurons. Supporting this hypothesis is the finding that the $\alpha$-NE antagonist piperoxane has been shown to alter the activity of A9 neurons indirectly through the serotonergic dorsal raphe system (Bunney and DeRiemer, 1982). Third, it is possible that CLZ affects postsynaptic DA receptors differently in striatal and limbic areas. For example, it has been found that intravenous CLZ blocks DA inhibitory effects in the nucleus accumbens (Aghajanian and Bunney, 1974) but not in the caudate nucleus (Bunney and Aghajanian, 1978). It has also been reported that CLZ prevents $\left[{ }^{3} \mathrm{H}\right]$ spiperone binding in cortical and limbic regions but not in the striatum (Kohler et al., 1981).

This inability to block DA effects in the caudate nucleus would suggest that CLZ may be unable to affect striatonigral and pallidonigral feedback pathway function. Such a lack of action might underlie its inability to induce depolarization inactivation in A9 cells. Our observations, that the destruction of these long-loop feedback pathways with intrastriatal kainic acid injections (Bunney and Grace, 1978) or transections blocks and reverses the ability of repeated HAL and CPZ administration, respectively, to decrease the number of active DA neurons encountered in A9, indirectly support this hypothesis. However, further studies testing these and other possibilities are obviously necessary if we are to understand the neuronal mechanisms underlying the lack of depolarization inactivation of A9 DA neurons associated with chronic CLZ treatment.

It has been well established, biochemically, that the neuroleptics $l$-SLP, CPZ, and HAL (as well as a variety of others) acutely increase DA turnover in lower mammals (Carlsson and Lindqvist, 1963; Anden and Stock, 
1973; Nyback et al., 1967; Nyback and Sedvall, 1970; Asper et al., 1973; Bowers and Rozitis, 1974; Scatton, 1977; Bannon et al., 1982b, 1983) as well as in human and nonhuman primates (Post and Goodwin, 1975; Roth et al., 1980; Bacopoulos et al., 1982). As proposed earlier (Bunney and Grace, 1978), our present data suggest that acute antipsychotic drug treatment increases DA release, at least in part, by activating normally silent DA neurons and increasing the activity of those DA neurons already firing (Bunney et al., 1973; Bunney, 1979). However, after repeated treatment tolerance develops to the biochemical effects of acute antipsychotic drug administration (Asper et al., 1973; Bowers and Rozitis, 1974; Post and Goodwin, 1975; Gerlach et al., 1975; Scatton, 1977; Bacopoulos et al., 1982). Various hypotheses have been proposed to explain this phenomenon. Our data suggest that this effect may, in part, be related to the progressive development of depolarization inactivation of both A9 and A10 DA neurons. Thus, one might expect that with the onset of depolarization there would be a concurrent reduction in the amount of DA released from the nerve terminal. When all of the DA neurons projecting to a given area have reached a state of depolarization inactivation, any release which still occurred would be greatly reduced and no longer impulse dependent.

Further support for the hypothesis that biochemical tolerance may be related to depolarization inactivation comes from a parallel between biochemical findings and our electrophysiological results with acute and chronic CLZ. Thus, it has been reported that DA neurons innervating limbic regions (predominantly A10 cells) develop tolerance to repeated CLZ administration whereas those projecting to the striatum (A9 cells) do not (Burki et al., 1974; Waldmeier and Maitre, 1976; Racagni et al., 1980). Our observations that repeated CLZ treatment resulted in depolarization block of A10 but not A9 DA cells could be the mechanism underlying this finding. However, arguing against our hypothesized relationship between the development of depolarization inactivation and biochemical tolerance is the report that biochemical tolerance to neuroleptics will occur in animals with kainic acid lesions of the striatum (DiChiara et al., 1977a, Scatton, 1980)

The present study indicates that mesocortical DA neurons projecting to the prefrontal cortex do not go into depolarization inactivation as a result of chronic neuroleptic treatment. This is in agreement with biochemical findings in lower mammals. (Scatton, 1977; Bannon et al., 1982a), as well as human and nonhuman primates (Roth et al., 1980; Bacopoulos et al., 1982), which demonstrate that both the increase in DA metabolites and the activation of tyrosine hydroxylase normally observed in the prefrontal cortex after acute neuroleptic treatment do not abate during chronic administration. It is these same DA neurons which lack autoreceptors (Bannon et al., 1981; L. A. Chiodo, M. J. Bannon, R. H. Roth, and B. S. Bunney, unpublished data). However, any causal relationship between this fact and the inability of these neurons to develop depolarization block remains obscure at this time. Moreover, the possibility that a higher dose or longer treatment might ultimately result in depolarization inactivation remains to be determined.
Clinical speculations. Do the sequences of electrophysiological events described above, which are associated with repeated neuroleptic treatment, underlie any of the time-dependent effects of antipsychotic drug administration observed clinically (Bunney and Grace, 1978)? One possibly related clinical action of these drugs might be their Parkinson-like side effects which can take days or weeks to develop fully (Klein et al., 1980; Jeste and Wyatt, 1982). The onset of these side effects cannot correspond to the blockade of postsynaptic DA receptors by antipsychotic drugs since this is known to occur immediately after acute administration. The lack of their development acutely might be explained by two facts: (1) neuroleptics are competitive inhibitors for DA receptors, and (2) an increased release of DA would occur acutely. The latter would result from: (1) the increase in the firing rate of spontaneously active DA cells, (2) the activation of normally silent DA cells, and (3) the blockade of DA nerve terminal autoreceptors (Kehr et al., 1972; Roth et al., 1975). All three actions would serve to reduce the postsynaptic receptor-blocking effects of these compounds by greately increasing the number of dopamine molecules within the synapse which would be available to compete with neuroleptic molecules for the DA receptor. Furthermore, it has recently been demonstrated that a $70 \%$ depletion of striatal DA must occur before Parkinson-like symptoms become manifest (Javoy-Agid et al., 1981). On the other hand, the hypothesized decrease in DA release associated with the time-dependent development of depolarization inactivation would, over time, reduce this initial competition between D $\Lambda$ and neuroleptic molecules for postsynaptic receptors. This would result in a progressively more effective blockade by these compounds and finally the emergence of extrapyramidal side effects. Such a sequence of events would also fit with the inability of CLZ to induce Parkinsonlike side effects. Thus, since biochemical results (Burki et al., 1974; Waldmeier and Maitre, 1976; Racagni et al., 1980) and our present electrophysiological findings demonstrate no difference between acute and repeated CLZ treatment, DA might continue to be released and, therefore, be available to compete with CLZ for postsynaptic DA receptors in the striatum.

The development of depolarization inactivation in A9 could also contribute to the development of tardive dyskinesia. The reduced availability of DA at the synapse (i.e., enhanced receptor blockade) would serve to potentiate the neuroleptic-induced sensitization of postsynaptic DA receptors which is generally believed to be a major factor in the development of tardive dyskinesia (Klawans, 1976; Baldessarini and Tarsy, 1976, 1980; Jeste and Wyatt, 1982). One could speculate that the inability of CLZ to induce depolarization block in A9 would reduce the development of $\mathrm{D} \Lambda$ receptor supersen. sitivity in the striatum. Receptor-binding studies support this notion since repeated CLZ treatment, unlike treatment with classical neuroleptics, has been reported not to increase postsynaptic DA receptor binding (Kobayashi et al., 1978; Creese and Snyder, 1980). 'These atypical actions of CLZ in the nigrostriatal DA system may, in part, explain why CLZ does not cause tardive dyskinesia even after long-term treatment. If correct, this hypoth- 
esis may have therapeutic implications. Thus, if it were possible to prevent the depolarization inactivation of A9 neurons normally produced by typical neuroleptics (perhaps by the concurrent treatment with a drug that "selectively" blocks striatal and/or pallidal influences on the substantia nigra), there might be a significant reduction in the extrapyramidal side effects associated with their use.

The progressive induction of depolarization inactivation in $A 10$ might also serve to explain the delayed onset of the therapeutic actions of antipsychotic drugs (Cotes et al., 1978; Beckmann et al., 1979; Crow et al., 1980; Klein et al., 1980). It is generally believed that the therapeutic effects of neuroleptics are due to the blockade of DA's action on postsynaptic receptors in the limbic and/or cortical regions (Meltzer and Stahl, 1976; Carlsson, 1978; Hornykiewicz, 1978; Bowers, 1980). Based on the same reasoning given above for the nigrostriatal DA system, a maximal reduction of DA influence postsynaptically would not be expected to develop until depolarization inactivation had taken place. Our present findings would be consistent with such a hypothesis since all the active neuroleptics tested produced depolarization inactivation of most A10 neurons. However, biochemical studies in lower animals (Scatton, 1977; Bannon et al., 1981), nonhuman primates, and humans (Roth et al., 1980; Bacopoulos et al., 1982) indicate that DA neurons projecting to the prefrontal cortex do not develop tolerance to repeated neuroleptic treatment. We have now shown that these DA neurons do not go into depolarization block following chronic antipsychotic drug administration. This would suggest that either our hypothesis is wrong or that the prefrontal mesocortical DA system may not be involved in some forms of psychosis.

Taken together our findings suggest that the technique of studying the population response of both A9 and A10 DA neurons may serve as a model system with which to dissociate - and, therefore, predict-the therapeutic and neurological side effect potential of putative neuroleptic compounds. In this model, chronic administration of neuroleptics which have clear therapeutic value (e.g., HAL, $l$-SLP, CPZ, and CLZ) would induce depolarization inactivation of A10 neurons. However, only those antipsychotics which are known also to produce extrapyramidal side effects (e.g., HAL, CPZ, $l$-SLP, but not CLZ) would inactivate A9 cells when given chronically. Obviously, many more known antipsychotic and nonantipsychotic drugs, as well as new unknown compounds, must be tested in this model before its validity can be established.

\section{References}

Aghajanian, G. K., and B. S. Bunney (1974) Dopaminergic and non-dopaminergic neurons of the substantia nigra: Differential responses to putative transmitters. In Neuropsychopharmacology, pp. 444-452, Excerpta Medica, Amsterdam.

Aghajanian, G. K., and B. S. Bunney (1977) Dopamine "autoreceptors": Pharmacological characterization by microiontophoretic single cell recording studies. Naunyn-Schmiedeberg's Arch. Pharmacol. 297: 1-7.

Anden, N. -E., and G. Stock (1973) Effects of clozapine on the turnover of dopamine in the corpus striatum and in the limbic system. J. Pharm. Pharmacol. 25: 346: 348.
Asper, H., M. Baggiolini, H. R. Burki, H. Lavener, W. Ruch, and G. Stille (1973) Tolerance phenomena with neuroleptics, catalepsy, apomorphine stereotypies and striatal dopamine metabolism in the rat after single and repeated administration of loxapine and haloperidol. Eur. J. Pharmacol. 22: 287294.

Bacopoulos, N. G., G. Bustos, D. E. Redmond, Jr., and R. H. Roth (1982) Chronic treatment with the haloperidol and fluphenazine decanoate: Regional effects of dopamine and serotonin metabolism in primate brain. J. Pharmacol. Exp. Ther. 221: 22-28.

Baldessarini, R. J., and D. Tarsy (1976) Mechanisms underlying tardive dyskinesias. In The Basal Ganglia, M. D. Yahr, ed., pp. 433-446, Raven Press, New York.

Baldessarini, R. J., and D. Tarsy (1980) Pathophysiologic basis of tardive dyskinesia. Adv. Biochem. Psychopharmacol. 24: 451-455.

Bannon, M. J., E. B. Bunney, J. R. Zigun, L. R. Skirboll, and R. H. Roth (1980) Presynaptic dopamine receptors: Insensitivity to kainic acid and the development of supersensitivity following chronic haloperidol. Naunyn-Schmiedeberg's Arch. Pharmacol. 312: 161-165.

Bannon, M. J., R. L. Michaud, and R. H. Roth (1981) Mesocortical dopamine neurons. Lack of autoreceptors modulating dopamine synthesis. Mol. Pharmacol. 19: 270-275.

Bannon, M. J., J. F. Reinhard, Jr., E. B. Bunney, and R. H. Roth (1982a) Unique response to antipsychotic drugs is due to absence of terminal autoreceptors in mesocortical dopamine neurons. Nature 296: 444-446.

Bannon, M. J., L. A. Chiodo, B. S. Bunney, and R. H. Roth (1982b) Mesocortical dopamine neurons. I. Electrophysiological and biochemical evidence for the absence of autoreceptors in a subpopulation. Soc. Neurosci. Abstr. 8: 480.

Bannon, M. J., M. E. Wolf, and R. H. Roth (1983) Pharmacology of dopamine neurons innervating the prefrontal, cingulate and entorhinal cortices. Eur. J. Pharmacol., in press.

Barbeau, A. (1969) L-Dopa therapy in Parkinson's disease: A critical review of nine years' experience. J. Can. Med. Assoc. 101: 791-800.

Bartholini, G., W. Haefely, M. Jalfre, H. H. Keller, and A. Pletscher (1972) Effects of clozapine on central catecholaminergic neurone systems. Br. J. Pharmacol. 46: 736.

Beckmann, B., H. Hippius, and E. Ruther (1979) Treatment of schizophrenia. Prog. Neuro-Psychopharmacol. 3: 47-52.

Berger, B. (1977) Histochemical identification and localization of dopaminergic axons in rat and human cerebral cortex. Adv. Biochem. Pharmacol. 16: 13-20.

Berger, B., J. P. Tassin, G. Blanc, M. A. Moyne, and A. M. Thierry (1974) Histochemical confirmation for dopaminergic innervation of the rat cerebral cortex after destruction of the noradrenergic ascending pathway. Brain Res. 81: 332-337.

Berger, B., A. M. Thierry, J. P. Tassin, and M. A. Moyne (1976) Dopaminergic innervation of the rat prefrontal cortex: A fluorescence histochemical study. Brain Res. 106: 133-145.

Bowers, M. B., and A. Rozitis (1974) Regional differences in homovanillic acid concentrations after acute and chronic administration of antipsychotic drugs. J. Pharm. Pharmacol. 26: 743-745.

Bowers, M. B., Jr. (1980) Biochemical processes in schizophrenia: An update. Schizophrenia Bull. 6: 393-403.

Bunney, B. S. (1979) The electrophysiological pharmacology of midbrain dopaminergic systems. In The Neurobiology of Dopamine, A. Horn, J. Korf, and B. H. C. Westerink, eds., pp. 417-452, Academic Press, London.

Bunney, B. S., and G. K. Aghajanian (1976) The precise localization of nigral afferents in the rat as determined by a retrograde tracing technique. Brain Res. 117: 423-435.

Bunney, B. S., and Aghajanian, G. K. (1978) Mesolimbic and 
mesocortical dopaminergic systems: Physiology and pharmacology. in Psychopharmacology: A Generation of Progress, M. A. Lipton, A. DiMascio, and K. F. Killam, eds., pp. 159169, Raven Press, New York.

Bunney, B. S., and A. A. Grace (1978) Acute and chronic haloperidol treatment: Comparison of effects on nigral dopaminergic cell activity. Life Sci. 23: 1715-1728.

Bunney, B. S., and S. DeRiemer (1982) Effects of clonidine on dopaminergic neuron activity in the substantia nigra: Possible indirect mediation by noradrenergic regulation of the serotonergic raphe system. In Gilles de la Tourette Syndrome, T. N. Chase and A. J. Friedhoff, eds., pp. 99-104, Raven Press, New York.

Bunney, B. S., J. R. Walters, R. H. Roth, and G. K. Aghajanian (1973) Dopaminergic neurons: Effect of antipsychotic drugs and amphetamine on single cell activity. J. Pharmacol. Exp. Ther. 185: 560-571.

Burki, H. R., W. Ruch, H. Asper, M. Baggiolini, and G. Stille (1974) Effect of single and repeated administration of clozapine on the metabolism of dopamine and noradrenaline in the brain of the rat. Fur. J. Pharmacol. 27: 180-190.

Carlsson, A. (1978) Mechanism of action of neuroleptic drugs. In Psychopharmacology: A Generation of Progress, M. A. Lipton, A. DiMascio, and K. F. Killam, eds., pp. 1057-1070, Raven Press, New York.

Carlsson, A., and M. Lindqvist (1963) Effects of chlorpromazine and haloperidol on formation of 3-methoxytyramine and normetanephrine in mouse brain. Acta Pharmacol. Toxicol. 20: 140-144.

Chiodo, L. A. (1981) Studies on the regulation of the responsiveness of substantia nigra dopamine neurons to sensory stimuli. Doctoral dissertation, University of Pittsburgh.

Chiodo, L. A., and S. M. Antelman (1980) Repeated tricyclics induce a progressive dopamine autoreceptor subsensitivity independent of daily drug treatment. Nature (Lond.) 287: $451-454$.

Chouinard, G., and L. Annable (1976) Clozapine in the treatment of newly admitted schizophrenic patients. A pilot study. J Clin. Pharmacol. 16: 289-297.

Cotes, M., T. J. Crow, E. C. Johnstone, W. Bartlett, and R. C. Bourne (1978) Neuroendocrine changes in acute shizophrenia as a function of clinical state and neuroleptic medication. Psychol. Med. 8: 657-665.

Crane, G. E. (1973) Persistent dyskinesia. Br. J. Psychiatry 122: $395-405$.

Creese, I., and S. H. Snyder (1980) Chronic neuroleptic treatment and dopamine receptor regulation. Adv. Biochem. Psychopharmacol, 24: 89-94.

Crow, T. J., A. J. Cross, E. C. Johnstone, A. Longden, F. Owen, and R. M. Ridley (1980) Time course of the antipsychotic effect in schizophrenia and some changes in postmortem brain and their relation to neuroleptic medication. Adv. Biochem. Psychopharmacol. 24: 495-503.

Dahlstrom, A., and K. Fuxe (1964) Evidence for the existence of monoamine-containing neurons in the central nervous system. I. Demonstration of monoamines in the cell bodies of brain stem neurons. Acta Physiol. Scand. Suppl. 62 (232): $1-55$.

Deniau, J. M., C. Hammond, A. Riszk, and J. Fegen (1978) Electrophysiological properties of identified output neurons of the rat substantia nigra (pars compacta and pars reticulata): Evidence for the existence of branched neurons. Exp. Brain Neurol. 32: 409-422.

DiChiara, G., M. L. Porceddu, W. Fratta, and G. L. Gessa (1977a) Postsynaptic receptors are not essential for dopaminergic feedback regulation. Nature 267: 271-272.

DiChiara, G., M. L. Porceddu, P. F. Sparo, and G. L. Gessa (1977b) Haloperidol increases and apomorphine decreases striatal dopamine metabolism after destruction of striatal dopamine-sensitive adenylate cyclase by kainic acid. Brain Res. 13: 374-382.

Donovick, P. J. (1974) A metachromatic stain for neural tissue. Stain Technol. 49: 49-51.

Gallager, D. W., A. Pert, and W. E. Bunney, Jr. (1978) Haloperidol-induced presynaptic dopamine supersensitivity is blocked by chronic lithium. Nature (Lond.) 273: 309-312.

Gerlach, J., P. Koppelhus, E. Helweg, and A. Monrad (1974) Clozapine and haloperidol in a single-bind cross-over trial: Therapeutic and biochemical aspects in the treatment of schizophrenia. Acta Psychiatr. 50: 410-424.

Gerlach, J., K. Thorsen, and R. Fog (1975) Extrapyramidal reactions and amine metabolites in cerebrospinal fluid during haloperidol and clozapine treatment of schizophrenic patients. Psychopharmacologia (Berl.) 40: 341-350.

Glowinski, J. (1975) Effects of neuroleptics on the nigroneostriatal and mesocortical dopaminergic systems. In Biology of Major Psychosis, D. X. Freedman, ed., pp. 233-246, Raven Press, New York.

Grace, A. A., and B. S. Bunney (1980) Nigral dopamine neurons: Intracellular recording and identification with L-DOPA injection and histofluorescence. Science 210: 654-656.

Grace, A. A., and B. S. Bunney (1983a) Intracellular and extracellular electrophysiology of nigral dopamine neurons. I. Identification and characterization. Neuroscience, in press.

Grace, A. A., and B. S. Bunney (1983b) Intracellular and extracellular electrophysiology of nigral dopaminergic neurons. II. Action potential generating mechanisms and morphological correlates. Neuroscience, in press.

Groves, P. M., C. J. Wilson, S. J. Young, and G. V. Rebec (1975) Self-inhibition of dopaminergic neurons. Science 190: 522-529.

Guyenet, P. G., and G. K. Aghajanian (1978) Antidromic identification of dopaminergic and other output neurons of the rat substantia nigra. Brain Res. 150:69-84.

Hokfelt, T., K. Fuxe, O. Johansson, and A. Lungdahl (1974) Pharmaco-histochemical evidence of the existence of dopamine nerve terminals in the limbic cortex. Eur. J. Pharmacol. 25: $108-112$.

Holcomb, H. H., M. J. Bannon, and R. H. Roth (1982) Striatal dopamine autoreceptors uninfluenced by chronic administration of antidepressants. Eur. J. Pharmacol. 82: 173-178.

Hornykiewicz, O. (1978) Psychopharmacological implications of dopamine and dopamine antagonists: A critical evaluation of current evidence. Neuroscience 3: 773-783.

Hyttel, J. (1974) Effect of neuroleptics on the disappearance rate of $\left[{ }^{14} \mathrm{C}\right]$ labelled catecholamines formed from $\left[{ }^{14} \mathrm{C}\right]$ tyrosine in mouse brain. J. Pharm. Pharmacol. 26: 588-596.

Javoy-Agid, F., H. Taquet, A. Ploska, C. Cherif-Zahar, M. Ruberg, and Y. Agid (1981) Distribution of catecholamines in the ventral mesencephalon of human brain, with special reference to Parkinson's disease. J. Neurochem. 36: 21012105.

Jeste, D. V., and R. J. Wyatt (1982) Understanding and Treating Tardive Dyskinesia, Guilford Press, New York.

Kane, J. M., and J. M. Smith (1982) Tardive dyskinesia: Prevalence and risk factors, 1959-1979. Arch. Gen. Psychiatry 39: 473-481.

Kebabian, J. W., and D. B. Calne (1979) Multiple receptors for dopamine. Nature 277: 93-96.

Kehr, W., A. Carlsson, M. Lindqvist, T. Magnusson, and C. V. Atack (1972) Evidence for a receptor-mediated feedback control of striatal tyrosine hydroxylase activity. J. Pharm. Pharmacol. 24: 744-746.

Klawans, H. L. (1976) Therapeutic approaches to neurolepticinduced tardive dyskinesia. In The Busul Ganglia, M. D. Yahr, ed., pp. 447-457, Raven Press, New York. 
Klawans, H. L. Jr., and R. R. McKendall (1971) Observations on the effects of levodopa on tardive lingual-facial-buccal dyskinesia. J. Neurol. Sci. 14: 189-192.

Klein, D. F., R. Gittelman, F. Quitkin, and A. Rifkin (1980) Diagnosis and Drug Treatment of Psychiatric Disorders: Adults and Children, Ed. 2, Williams \& Wilkins, Baltimore.

Kobayashi, R. M., J. X. Fields, R. E. Hruska, K. Beaumont, and H. I. Yamamura (1978) Brain neurotransmitter receptors and chronic antipsychotic drug treatment: A model for tardive dyskinesia. In Animal Models in Psychiatry, I. Hanin and E. Usdin, eds., pp. 405-409, Pergamon Press, New York.

Kohler, C., L. Haglund, S. -O. Ogren, and T. Angeby (1981) Regional blockade by neuroleptic drugs of in vivo ${ }^{3} \mathrm{H}$-spiperone binding in the rat brain. Relation to blockade of apomorphine induced hyperactivity and stereotypies. J. Neurol. Trans. 52: 163-173.

Konig, J. F. R., and R. A. Klippel (1974) The Rat Brain: A Stereotaxic Atlas, Williams \& Wilkins, Baltimore.

Laduron, P., K. DeBie, and J. Leysen (1977) Specific effects of haloperidol on dopamine turnover in the frontal cortex. Naunyn-Schmiedeberg's Arch. Pharmacol. 296: 183-185.

Lerner, P., P. Nose, E. Gordon, and W. Lovenberg (1977) Haloperidol: Effects of long-term treatment on rat striatal dopamine synthesis and turnover. Science 197: 181-183.

Lindvall, O. (1979) Dopamine pathways in the rat brain. In The Neurobiology of Dopamine, A. S. Horn, J. Korf, and B. H. C. Westerink, eds., pp. 319-342, Academic Press, New York.

Lindvall, O., A. Bjorklund, and I. Divac (1977) Organization of mesencephalic dopamine neurons projecting to the neocortex and septum. Adv. Biochem. Psychopharmacol. 16: 39-46.

Lindvall, O., and A. Bjorklund (1978) Anatomy of the dopaminergic neuron systems in the rat brain. Adv. Biochem. Psychopharmacol. 19: 1-23.

Marco, E., C. C. Mao, D. L. Cheney, A. Revuelta, and E. Costa (1976) The effects of antipsychotics on the turnover rate of GABA and acetylcholine in rat brain nuclei. Nature 264: 363-365.

Matthysse, S. (1973) Antipsychotic drug actions: A clue to the neuropathology of schizophrenia? Fed. Proc. 32: 200-205.

McMillen, B. A., and P. A. Shore (1978) Comparative effects of clozapine and alpha-adrenoceptor blocking drugs on regional noradrenaline metabolism in rat brain. Eur. J. Pharmacol. 52: 225-230.

Meller, E., A. J. Friedhoff, and E. Friedman (1980) Differential effects of acute and chronic haloperidol treatment on striatal and nigral 3,4-dihydroxyphenylacetic acid (DOPAC) levels. Life Sci. 26: 541-547.

Meltzer, H. Y., and S. M. Stahl (1976) The dopamine hypothesis of schizophrenia: A review. Schizophrenia Bull. 2: 19 76.

Miller, R. J., and C. R. Hiley (1974) Anti-muscarinic properties of neuroleptics and drug induced parkinsonism. Nature 248 . 596-597.

Nyback, H., and G. Sedvall (1970) Further studies on the accumulation and disappearance of catecholamines formed from tyrosine $-{ }^{14} \mathrm{C}$ in mouse brain. Effects of some phenothiazine analogues. Eur. J. Pharmacol. 10: 193-205.

Nyback, H., G. Sedvall, and I. J. Kopin (1967) Accelerated synthesis of dopamine- $\mathrm{C}^{14}$ from tyrosine- $\mathrm{C}^{14}$ in rat brain after chlorpromazine. Life Sci. 6: 2307-2312.

O'Conner, S. E., and R. A. Brown (1982) The pharmacology of sulpiride-a dopamine receptor antagonist. Gen. Pharmacol. 13: 185-193.

Pelham, R. W., and T. L. Munsat (1979) Identification of direct competition for, and indirect influences on, striatal muscarinic cholinergic receptors: In vivo $\left({ }^{3} \mathrm{H}\right)$-quinuclidinyl benzilate binding in rats. Brain Res. 171: 473-480.
Post, R. M., and F. K. Goodwin (1975) Time-dependent effects of phenothiazines on dopamine turnover in psychiatric patients. Science 190: 488-489.

Racagni, G., F. Bruno, A. Bugatti, M. Parenti, J. A. Apud, V. Santini, A. Carenzi, A. Groppetti, and F. Catabeni (1980) Behavioral and biochemical correlates after haloperidol and clozapine long-term treatment. Adv. Biochem. Psychopharmacol. 24: 45-51.

Roth, R. H., V. H. Morgenroth, and L. C. Murrin (1975) The effects of antipsychotic drugs and impulse flow on the kinetics of striatal tyrosine hydroxylase. in Antipsychotic Drugs: Pharmacodynamics and Pharmacokinetics, G. Sedvall, ed., pp. 133-145, Pergamon Press, New York.

Roth, R. H., N. G. Bacopoulos, G. Bustos, and D. E. Redmond, Jr. (1980) Antipsychotic drugs: Differential effects on dopamine neurons in basal ganglia and mesocortex following chronic administration in human and non-human primates. Adv. Biochem. Psychopharmacol. 214: 513-520.

Salmoiraghi, G. G., and F. Weight (1967) Micromethods in neuropharmacology: An approach to the study of anesthetics. Anesthesiology 28: 51-61.

Scatton, B. (1977) Differential regional development of tolerance to increase in dopamine turnover upon repeated neuroleptic administration. Eur. J. Pharmacol. 46: 363-369.

Scatton, B. (1980) Effect of repeated treatment with neuroleptics on dopamine metabolism in cell bodies and terminals of dopaminergic systems in the rat brain. Adv. Biochem. Psychopharmacol. 24: 31-36.

Scatton, B., L. Garrett, and L. Julou (1975) Acute and subacute effects of neuroleptics on dopamine synthesis and release in the rat striatum. Naunyn-Schmiedeberg's Arch. Pharmacol. 289: 419-434.

Serra, G., A. Argiolas, V. Klimek, F. Fadda, and G. L. Gessa (1979) Chronic treatment with antidepressants prevents the inhibitory effect of small doses of apomorphine on dopamine synthesis and motor activity. Life Sco. 25: 415-424.

Serra, G., A. Argiolas, and G. L. Gessa (1981) Opposite changes in DA autoreceptor sensitivity induced by chronic antidepressants and neuroleptics. In Apomorphine and Other Dopaminomimetics. Vol. 1: Basic Pharmacology, G. L. Gessa and G. V. Corsini, eds., pp. 133-142, Raven Press, New York.

Shopsin, B., H. Klein, M. Aaronsom, and M. Collora (1979) Clozapine, chlorpromazine, and placebo in newly hospitalized, acutely schizophrenic patients. A controlled, doubleblind comparison. Arch. Gen. Psychiatry 36: 657-664.

Snyder, S. H. (1972) Catecholamines in the brain as mediators of amphetamine psychosis. Arch. Gen. Psychiatry 27: 169179.

Snyder, S. H., S. P. Banerjee, II. I. Yamamura, and D. Greenburg (1974) Drugs, neurotransmitters and schizophrenia. Science 184: 1243-1253.

Souto, M., J. M. Monti, and H. Alter (1979) Effects of clozapine on the activity of control dopaminergic and noradrenergic neurons. Pharmacol. Biochem. Behav, 10: 5-9.

Sovner, R., and A. DiMascio (1978) Extrapyramidal syndromes and other neurological side effects of psychotropic drugs. In Psychopharmacology: A Generation of Progress, M. A. Lipton, A. DiMascio, and K. F. Killam, eds., pp. 1021-1032, Raven Press, New York.

Stevens, J. R. (1973) An anatomy of schizophrenia? Arch. Gen. Psychiatry 29: 177-189.

Swanson, L. W. (1982) The projections of the ventral tegmental area and adjacent regions: A combined fluorescent retrograde tracer and immunofluorescence study in the rat. Brain Res. Bull. 9: 321-353.

Waldmeier, P. C., and L. Maitre (1976) Clozapine: Reduction of the initial dopamine turnover increase by repeated treatment. Eur. J. Pharmacol. 38: 197-203. 
Wang, R. Y. (1981) Dopaminergic neurons in the rat ventral tegmental area. III. Effect of D- and L-amphetamine. Brain Res. Bull. 3: 153-165.

Wheeler, S. C., and R. H. Roth (1980) Tolerance to fluphenazine and supersensitivity to apomorphine in central dopaminergic systems after chronic fluphenazine treatment. Naunyn-Schmiedeberg's Arch. Pharmacol. 312: 151-159.

White, F. J., and R. Y. Wang (1983) Comparison of the effects of chronic haloperidol treatment on A9 and A10 dopamine neurons in the rat. Life Sci. 32: 983-993.

Wilk, S., and M. Stanley (1978) Clozapine concentrations in brain regions: Relationship to dopamine metabolite increase. Eur. J. Pharmacol. 51: 101-107.

Will, S., E. Watson, and M. E. Stanley (1975) Differential sensitivity of two dopaminergic structures in rat brain to haloperidol and to clozapine. J. Pharmacol. Exp. Ther. 195: $265-270$.

Zivkovic, B., A. Guidotti, A. Revuelta, and E. Costa (1975) Effects of thioridazine, clozapine and other antipsychotics on the kinetic state of dopamine in striatum and nucleus accumbens. J. Pharmacol. Exp. Ther. 194: 37-46. 